\title{
Paleomagnetism of the Devonian Catskill Red Beds: Evidence for Motion of the Coastal New England-Canadian Maritime Region Relative to Cratonic North America
}

\author{
Dennis V. Kent and Neil D. Opdyke \\ Lamont-Doherty Geological Observatory of Columbia University \\ Palisades, New York 10964
}

\begin{abstract}
The natural remanent magnetizations of reddish clay stones, siltstones, and sandstones from the nearly flat lying Middle to Upper Devonian Catskill sequence of southeastern New York were analyzed with thermal, alternating field, and chemical demagnetization techniques. After removal of a low blocking temperature component along the present geomagnetic field direction a characteristic direction of magnetization was isolated: $D=172.3^{\circ}, I=1.0^{\circ}, k=116$, and $\alpha_{\theta 8}=4.7^{\circ}$ for $N=9$ sites (43 samples), giving a paleomagnetic north pole at $46.8^{\circ} \mathrm{N}, 116.7^{\circ} \mathrm{E}, d p=2.4^{\circ}$, and $d m=4.7^{\circ}$. The combined demagnetization analyses show this to be the only stable component of magnetization present in these rocks. The derived pole position agrees well with the poles reported for some Devonian limestones in Ohio, all falling near the Permian poles for North America, but disagrees with Devonian results from eastern Maine-New Brunswick and eastern Massachusetts which give poles at lower latitudes. A similar geographical grouping with similar directions is also apparent for Lower Carboniferous (Mississippian) paleomagnetic poles for North America. We interpret these and other late Paleozoic paleomagnetic data to show that the coastal Canadian Maritime-New England region was not an integral part of cratonic North America until about the Late Carboniferous. Geological considerations suggest that the Carboniferous relative motion was along transcurrent shear zones.
\end{abstract}

\section{INTRODUCTION}

The Devonian paleomagnetic field for North America is not well known; there are few published data, and those that are available show considerable scatter. Consequently, the position of North America with respect to the earth's rotation axis and to the other continents lacks adequate definition for paleogeographic reconstructions and plate tectonic analysis in the mid-Paleozoic.

Until recently, results considered to be representative of the Devonian of North America came from paleomagnetic studies chiefly of lavas and red beds of the Upper Devonian Perry Formation of Maine and New Brunswick [Black, 1964; Phillips and Heroy, 1966; Robertson et al., 1968]. However, a recent investigation of Lower to Middle Devonian limestones from Ohio [Martin, 1975] gave a paleomagnetic pole near to the late Paleozoic pole position for North America and some $15^{\circ}$ away from the mean Perry pole. It is difficult to attribute the difference in the pole position to a particular cause, such as apparent polar wander with respect to North America in the Devonian, without additional data.

This report describes a paleomagnetic study of reddish siltstones and sandstones within the Middle to Upper Devonian Catskill deposits of New York. The results of this study enable us to propose a resolution to the apparent discrepancy in North American Devonian paleomagnetic data on the basis of paleogeography and to discuss the relevance of these and other late Paleozoic paleomagnetic data to the formation of the Euramerican supercontinent.

\section{Geologic Setting AND Sampling}

The Catskill area of New York has been regarded for over a century as a classic region in which to study the Devonian system of North America. Within the Devonian rocks of southeastern New York, there are approximately 5000 feet $(1524 \mathrm{~m})$ of interbedded red and gray sandstones, shales, and

Copyright (c) 1978 by the American Geophysical Union.

Paper number 8B0574.

0148-0227/78/098B-0574\$01.00 conglomerates known collectively as 'Catskill.' These predominantly nonmarine terrigenous sediments of Middle and Upper Devonian age extend to Pennsylvania and the Virginias, while they thin to the west and grade to marine equivalents. The semilenticular form of the deposit and its great thickness reflect accumulation in a progressively subsiding foredeep or exogeosyncline within the border of the early Paleozoic craton; the sediment was evidently eroded from source lands to the east and southeast raised in the Acadian orogeny.

The complex intertonguing and intergrading of Catskill strata make regional stratigraphic relationships difficult to unravel, and various interpretations of the detailed stratigraphy have been proposed. We follow here the subdivision of the clastic rocks at the Catskill front used by Fletcher [1967] and essentially followed in the geological map of New York [D.W. Fisher et al., 1970]. This interpretation recognizes cyclic sedimentation alternating between red bed units and dark gray shales and sandstones. The red beds form large tongues that are thickest to the east at the Catskill front and which pinch out progressively farther to the west going up the section.

A total of 46 oriented drill core samples distributed over nine sites was collected from within three red siltstone and red sandstone units in the Catskill beds: seven sites were in the Upper Devonian Walton Formation, and a site was taken in both the Plattekill Formation and the Manorkill Formation, which are of Middle Devonian age (Figure 1 and Table A1) [Fletcher, 1967]. Generally, two specimens $(2.5 \mathrm{~cm}$ in diameter and $2.0 \mathrm{~cm}$ high) were obtained from each sample for magnetic measurements. The strata sampled were nearly flat lying, with bedding dips of less than $5^{\circ}$; structural complications of the late Paleozoic Appalachian orogeny, which resulted in folding of similar beds just to the southwest in northern Pennsylvania, are apparently not present in this area. On the other hand it was not possible to do a fold test [Graham, 1949] to delimit the age of the remanent magnetization of these rocks, and detailed laboratory analyses of the magnetizations are necessary to assess their significance. 


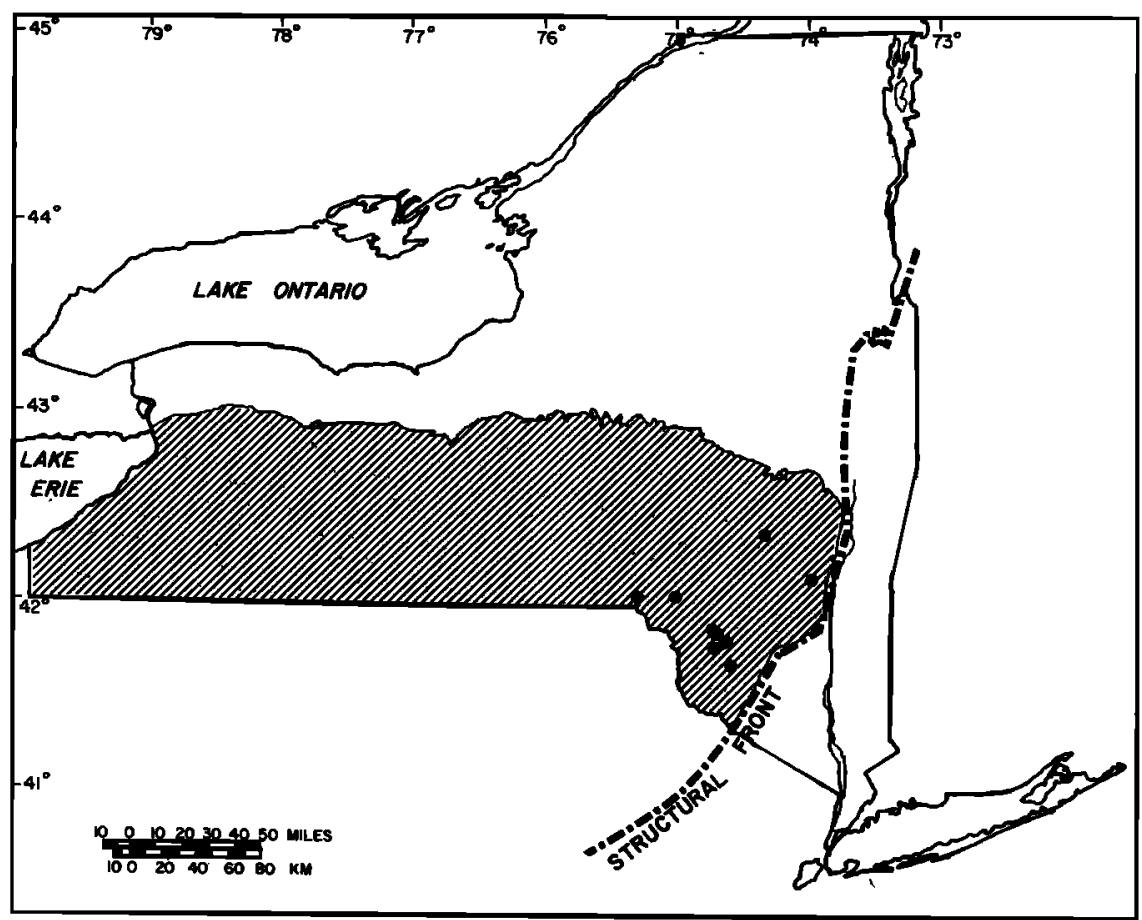

Fig. 1. Location of paleomagnetic sampling sites in the Middle to Upper Devonian Catskill sequence. The hatched area shows the outcrop of Middle to Upper Devonian sediments in New York. Lower Devonian and older formations are typically folded and faulted to the east of the structural front in New York, while Devonian strata to the west are essentially flat lying.

\section{Measurement and Demagnetization Analysis}

The direction and intensity of the natural remanent magnetization (NRM) of each sample specimen were measured with a computerized 7-Hz spinner magnetometer [Molyneux, 1972]. The NRM intensities range between $5 \times 10^{-8}$ and $2 \times 10^{-5}$ $\mathrm{emu} / \mathrm{g}$ but are typically near the average of $2.2 \times 10^{-6} \mathrm{emu} / \mathrm{g}$.
The NRM directions show considerable scatter but are dominantly dipping down and to the south, away from the present geomagnetic field direction (Figure $2 a$ ). Progressive thermal, alternating field (AF), and chemical demagnetization experiments were performed to establish the nature of the magnetizations and to isolate a characteristic direction for these rocks.

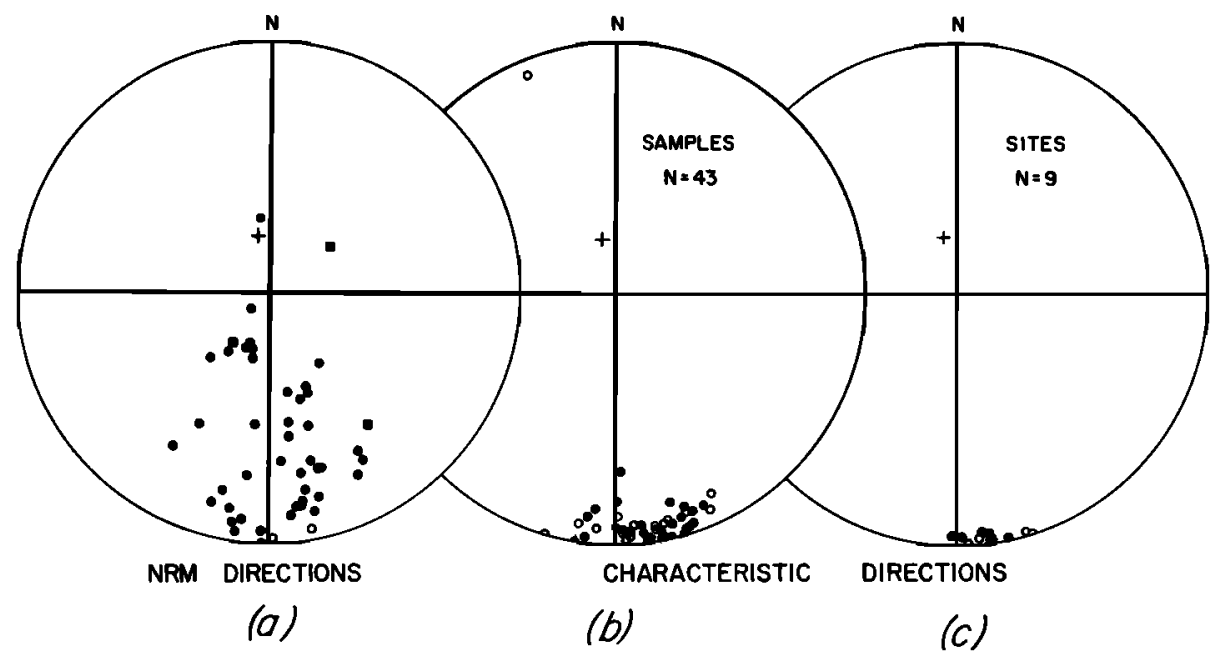

Fig. 2. (a) Plots of NRM directions and $(b, c)$ characteristic directions based on thermal demagnetization for Catskill red beds. Solid (open) circles are on the lower (upper) hemisphere. Pluses represent the present geamagnetic field direction in the sampling area. Squares represent samples in which the characteristic direction could not be determined. 

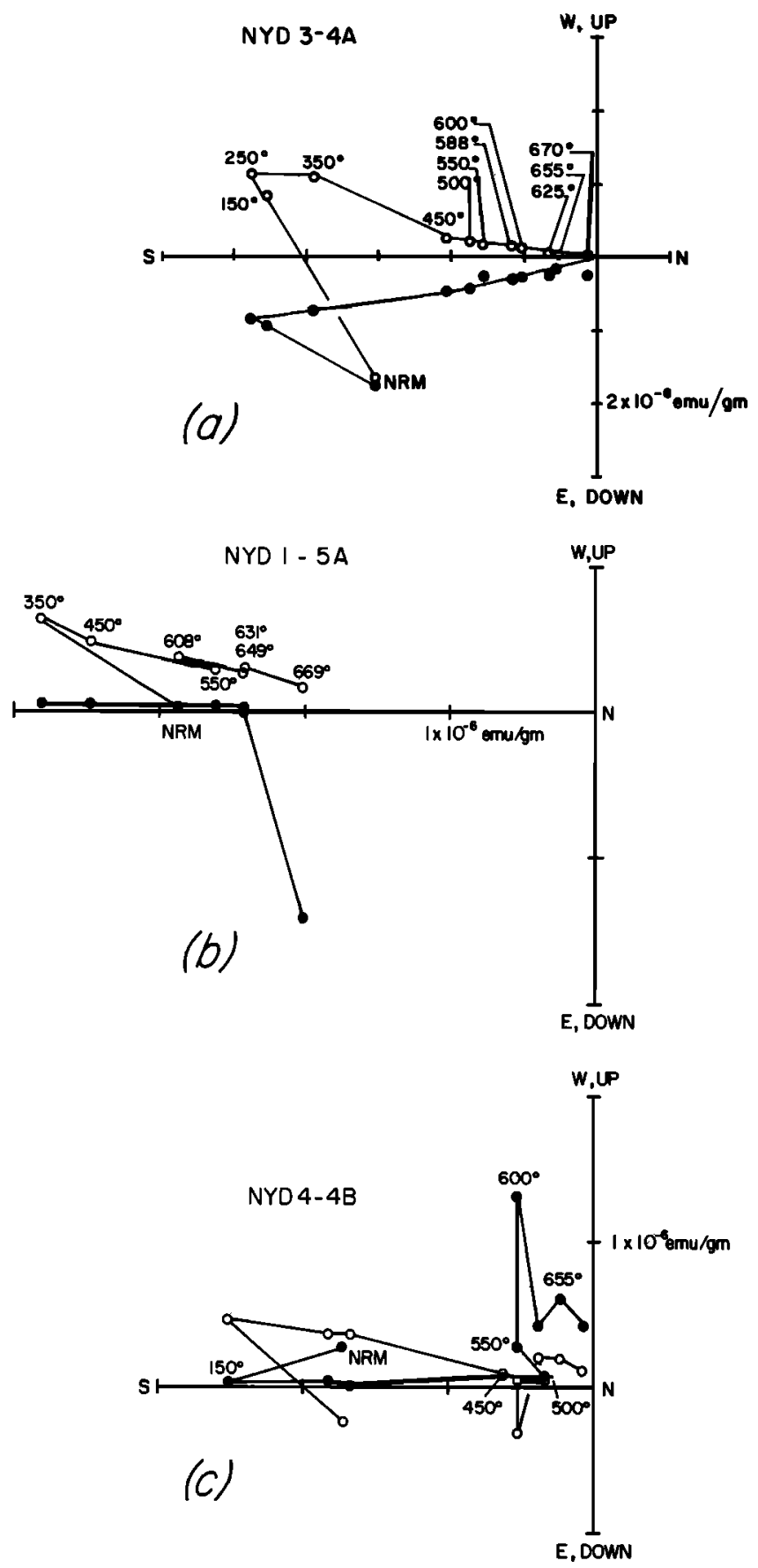

Fig. 3. Vector diagrams of progressive thermal demagnetization of Catskill red bed samples. Open symbols represent projections on the north-south plane, and solid symbols those on the horizontal plane. The numbers next to the symbols are the thermal demagnetization temperatures (degrees Celsius).

\section{Thermal Demagnetization Studies}

Figure 3 shows the change in direction and intensity of the NRM of representative specimens with progressive thermal demagnetization, plotted according to the Zijderveld [1967] method. These diagrams illustrate the range of behavior exhibited by these rocks as the result of heating, particularly to higher temperatures.

The low and intermediate temperature characteristics are nearly the same for all samples. Initial heatings produce a change in direction, often accompanied by an increase in intensity, resulting from the removal of a magnetization com- ponent which dips down and toward the north (Figures $3 a-$ $3 c$ ). Although the directions of this low blocking temperature magnetization are not very well defined, they generally conform to the present geomagnetic field direction, and these components can be assumed to be of recent origin. Above temperatures of $150^{\circ}-350^{\circ} \mathrm{C}$ the trajectory of further demagnetization tends to be linear toward the origin until little magnetization remains after $670^{\circ} \mathrm{C}$ (Figure $3 a$ ). The high blocking temperature suggests that the carrier of the stable remanence is hematite which occurs as small aggregates and as a coating and cement around the grains. However, most of the samples studied did not show this continued linear decay to near the origin in the higher temperature range of demagnetization but rather followed one of two other types of behavior.

In the first type, there is little further change in direction, but a substantial fraction of the NRM still remains up to temperatures of $650^{\circ}-670^{\circ} \mathrm{C}$; treatment at slightly higher temperatures results in what we interpret as spurious magnetizations for the reasons discussed below (Figure $3 b$ ). We attribute this behavior to a thermally discrete component of magnetization [Irving and Opdyke, 1965] in which the spectrum of blocking temperatures is concentrated in a small range below about $670^{\circ} \mathrm{C}$, near to the Curie temperature of hematite. The second type shows the onset of scattered directions and large fluctuations in magnetization intensity at temperatures varying from $500^{\circ} \mathrm{C}$ to over $620^{\circ} \mathrm{C}$ from sample to sample as the intermediate temperature range trajectory approaches the origin (Figure $3 c$ ). This erratic behavior at high temperatures appears to be associated with a marked physicochemical change in the original magnetic mineralogy that occurred as the result of heating the samples in the laboratory.

A clear indication of magnetic mineral change is given by the remeasurement (at room temperature) of magnetic susceptibility of specimens after they have been heated to successively

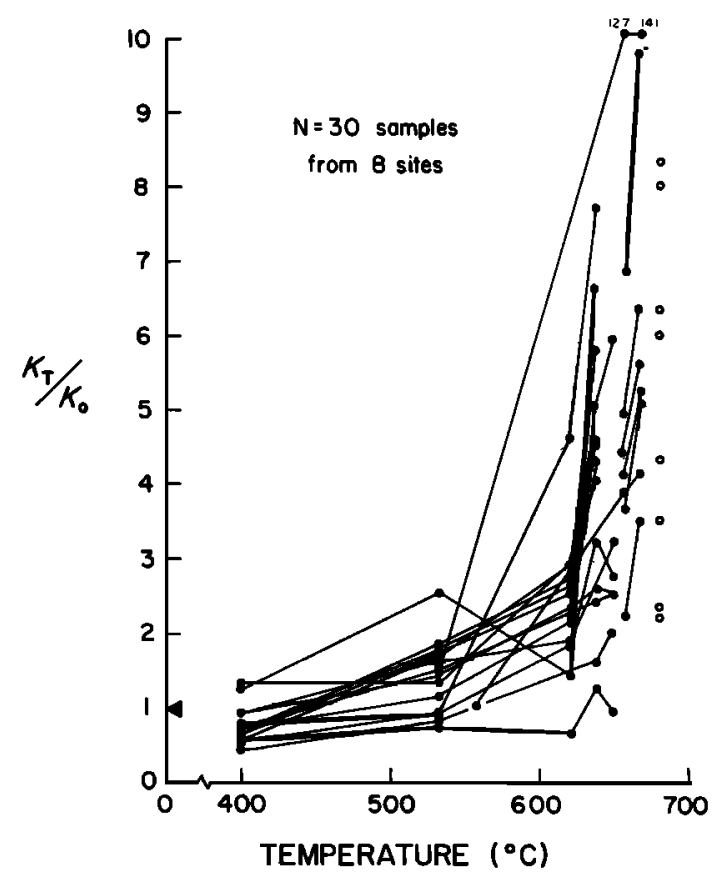

Fig. 4. Change in room temperature initial susceptibility expressed as the ratio to the original value $\left(k_{t} / k_{0}\right)$ as the result of heating Catskill red bed samples in air. The susceptibility was sometimes not measured after every heating of each sample. For clarity, lines connecting to the initial value $\left(k_{t} / k_{0}=1\right)$ have not been drawn. The open circles show sample susceptibilities remeasured only after thermal demagnetization analysis was completed. 

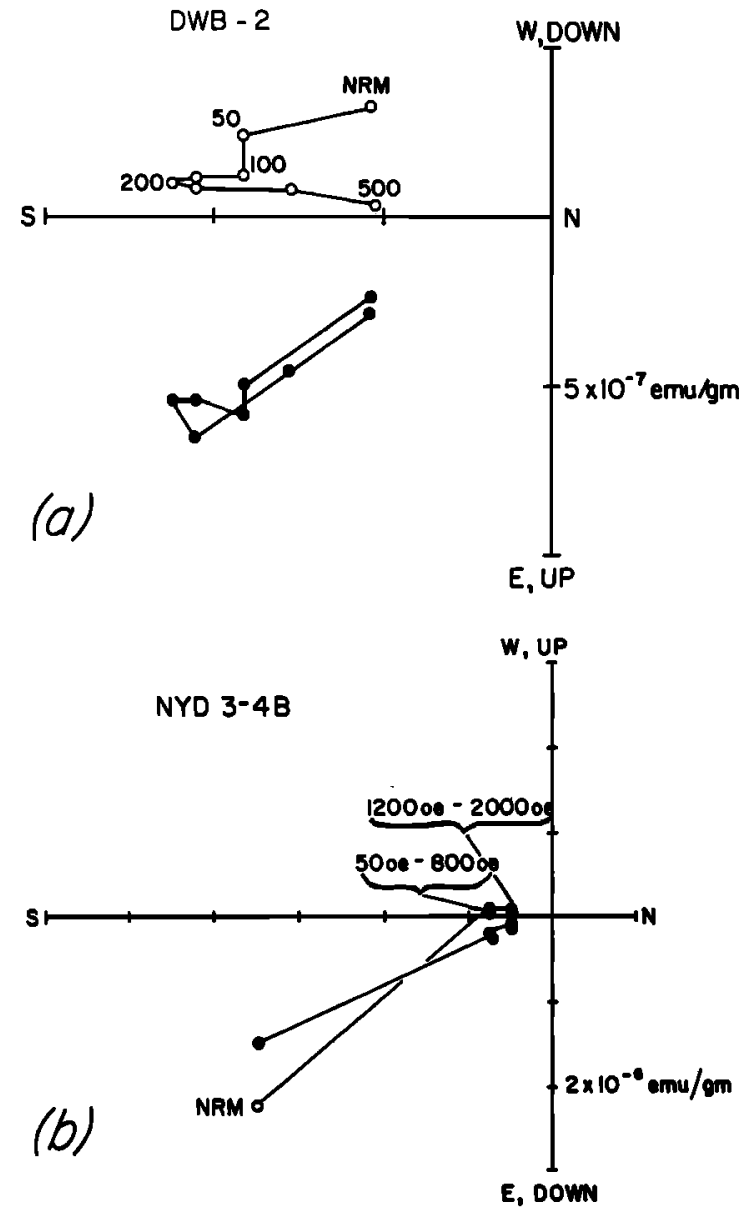

Fig. 5. Comparison of remanent hysteresis of Catskill red bed samples before and after heating in air.

higher temperatures (Figure 4). The susceptibilities are generally near or slightly less than their initial values after $400^{\circ} \mathrm{C}$, appear to increase gradually at temperatures of up to about $620^{\circ} \mathrm{C}$, and then show a rapid increase with higher temperatures, at which the susceptibilities can become an order of magnitude greater than they were originally. Besides susceptibility the remanent magnetic properties also change after thermal treatment, as is indicated by comparison of acquisition of isothermal remanence and of remanent coercivity of heated and unheated companion specimens. The unheated specimens all show a gradual increase in remanence with applied field but do not reach saturation by $7 \mathrm{kOe}$, the highest field used. There is a smooth decrease in remanence with field applied in the reverse direction, and remanent coercivities are typically about $3 \mathrm{kOe}$ (Figures $5 a$ and $5 b$ ). The heated specimens, however, are generally characterized by a large initial increase in remanent intensity at relatively low fields, and although saturation again is not reached by $7 \mathrm{kOe}$, the much reduced value of remanent coercivity shows that the low coercivity fraction now dominates the magnetization of most of the heated samples (Figure $5 a$ ). Although changes in magnetic properties at elevated temperatures commonly occurred, the effects of heating were less drastic in some samples. For example, a sample from site 3 was only partially affected by heating, and much of its original remanent magnetic properties remained; two coercivity fractions can be readily distinguished by the kink in the remanent coercivity curve (Figure $5 b$ ). Samples from this site had good thermal demagnetization characteristics (e.g., Figure $3 a$ ) and showed only relatively small changes in susceptibility after heating (e.g., the lowest curve in Figure 4). Nevertheless, the production of a large, dominant soft component of magnetization which is likely to be affected by stray magnetic fields present in the laboratory during thermal demagnetization and measurement is the probable cause for the confused demagnetization results observed at higher temperatures in many samples of the Catskill red beds. Apparently, either hematite or some nonmagnetic, iron-bearing mineral in the rock has been converted during thermal treatment to a highly magnetic phase, such as magnetite [H. P. Johnson et al., 1972; Dunlop, 1972].

The introduction of spurious magnetizations due to physicochemical changes at various temperatures prohibited blanket thermal cleaning at a single temperature of all samples. Consequently, each sample was thermally demagnetized at a minimum of four temperature steps, typically in the range $350^{\circ}-650^{\circ} \mathrm{C}$, and a characteristic direction was obtained from the demagnetization trajectory which was linear toward the origin. The directions of the sample characteristic magnetizations could be determined in this manner for all but three unstable samples and are shown in Figure $2 b$. These directions cluster well with the exception of one sample from site DPA
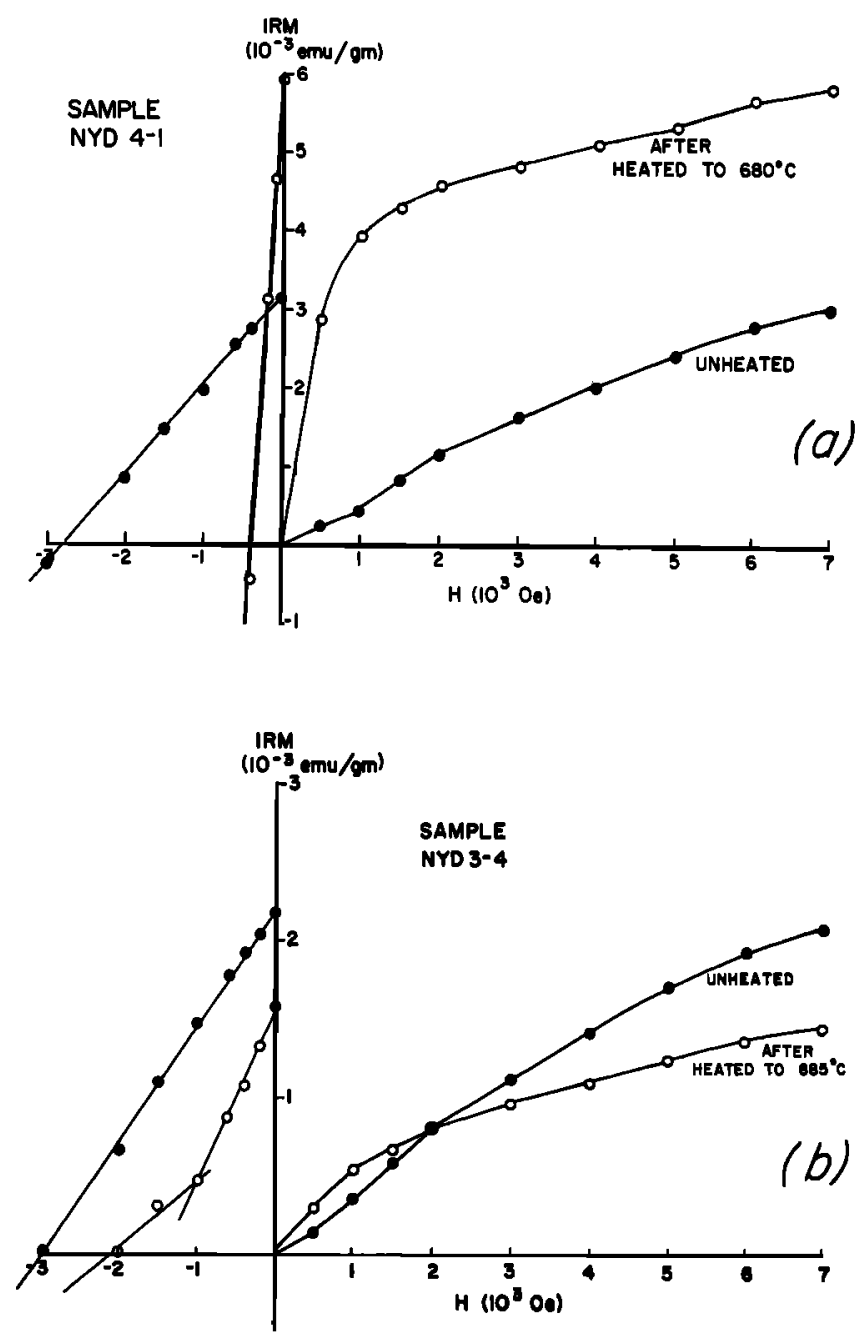

Fig. 6. Vector diagrams of progressive alternating field demagnetization of Catskill red bed samples. The open symbols represent projections on the north-south plane, and the solid symbols those on the horizontal plane. The numbers next to the symbols are the demagnetizing fields in peak oersteds. 
whose direction is almost exactly antiparallel to that of the others and which may represent a paleomagnetic reversal.

\section{AF Demagnetization}

The NRM of a suite of specimens from the nine sites was treated in progressively higher alternating fields. All specimens behaved similarly, and representative demagnetization diagrams are shown in Figure 6. It is evident that fields of only 50-200 Oe are effective in removing a component near to the direction of the present field (Figure 6a). Thus the secondary magnetization in these rocks is characterized as being of low coercivity as well as of low blocking temperature. In contrast, the component with a trajectory tending toward the origin is of high coercivity, stable against alternating fields as high as are available ( $2000 \mathrm{Oe})$, which is consistent with a hematite remanence carrier as inferred from the thermal experiments. The direction of this high-stability component is similar to that of the characteristic magnetization isolated in thermal demagnetization of companion specimens (i.e., compare Figures $6 b$ and $3 a$, and see Figure 7).

\section{Chemical Demagnetization}

Disks, $1 \mathrm{~cm}$ thick, were cut from several specimens and were leached in $10 \mathrm{~N}$ hydrochloric acid at room temperature (and in the earth's magnetic field) over a period of up to 25 days. The disks were removed from the acid periodically for remeasurement of their magnetizations at which times the acid bath was replenished. Typical effects of the acid treatment on the magnetizations are illustrated in Figure 8. All the specimens showed a decrease in remanent intensity with duration in acid until between $10 \%$ and $40 \%$ of the original magnetization remained after 25 days. However, the decrease was uniform in some samples and more erratic in others (Figure 8a). Samples showing uniform decrease usually showed only a small change in direction in the first 10 days, after which the directions stayed constant, with shallow dips toward the south. The lack of significant directional change with chemical demagnetization in these particular samples may be due to the fact that they had acquired little secondary magnetization.

In contrast, the remanent directions of the specimens with the erratic intensity decay curves continued to change over the

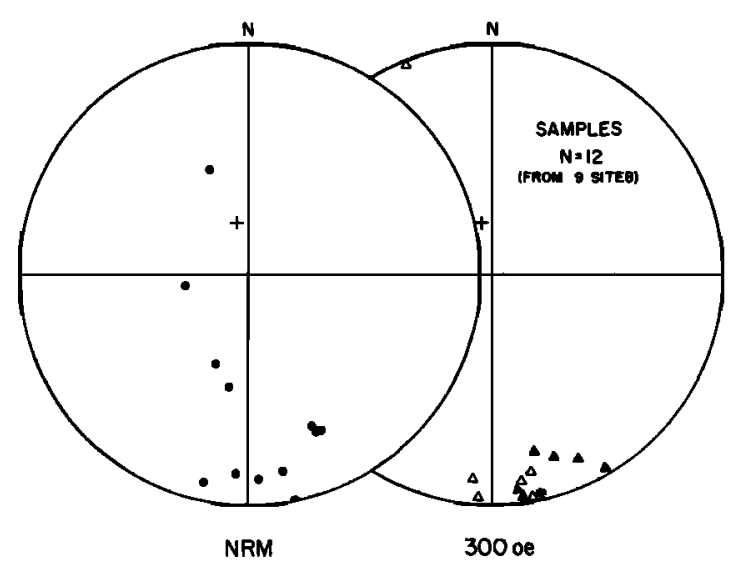

Fig. 7. Directions of NRM before and after the demagnetization to 300 Oe of 12 samples of Catskill red beds. Mean direction after 300 Oe (inverting the direction of the northerly pointing sample) is $D=$ $167.8^{\circ}, I=2.7^{\circ}$, and $\alpha_{\theta B}=8.8^{\circ}$.
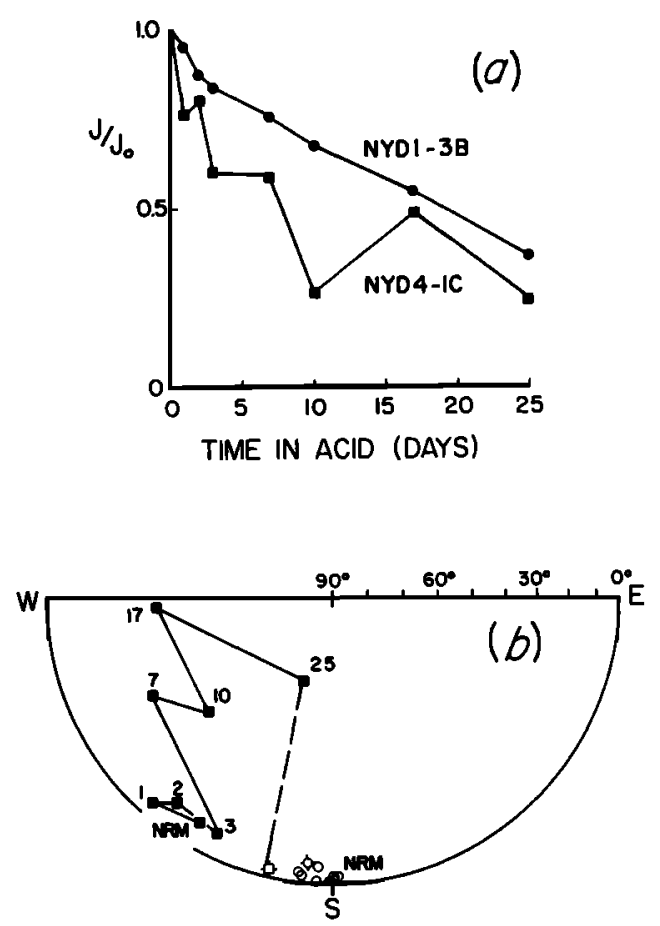

Fig. 8. Plots of $(a)$ the change in the intensity and $(b)$ the corresponding change in directions of the NRM of two Catskill red bed samples with time in $10 \mathrm{~N}$ hydrochloric acid. The crossed symbols in Figure $8 b$ refer to the direction after 150 Oe of AF demagnetization was applied after 25 days in acid; the numbers next to the symbols refer to time in acid in days.

course of the experiment in a rather haphazard fashion but with a tendency to move toward the present magnetic field direction. Interestingly, subsequent AF demagnetization at relatively low fields brings the directions to close agreement with those of the better-behaved samples (Figure $8 b$ ) which together are near to the characteristic directions obtained from thermal and AF demagnetization analyses. Evidently, the acid leaching preferentially removes the high coercivity and high blocking temperature magnetization thereby allowing the soft, secondary component to dominate. If this interpretation is correct, chemical demagnetization (of the type performed here) cannot be considered an effective method of 'cleaning' in these rocks.

\section{Results and Paleomagnetic Pole Position}

The site mean directions are summarized in Table 1 and are shown in Figure $2 c$. There is no significant difference between directions of the Middle Devonian sites and those of the Upper Devonian sites. The mean direction obtained from all nine site means is declination, $172.3^{\circ}$ and inclination, $1.0^{\circ}\left(\alpha_{95}\right.$ $=4.7^{\circ}$ ), which gives a paleomagnetic pole position at $46.8^{\circ} \mathrm{N}$, $116.7^{\circ} \mathrm{E}\left(d p=2.4^{\circ}, d m=4.7^{\circ}\right)$. Since we can find no evidence of any other consistent stable magnetization direction in these rocks, we tentatively assume that this direction represents a record of the Middle to Late Devonian paleomagnetic field for North America. The generally higher within-site dispersion compared to between-site dispersion in characteristic directions (Table 1) suggests that secular variation is effectively averaged by sampling over several meters of section at each site. 
TABLE 1. Site Mean Directions of Characteristic Magnetization

\begin{tabular}{llccrrr}
\hline \multicolumn{1}{c}{ Site } & Age & $R s$ & $\begin{array}{c}\text { Declination, } \\
\text { deg }\end{array}$ & $\begin{array}{c}\text { Inclination, } \\
\text { deg }\end{array}$ & $\alpha_{\text {Bb }}$ & $k$ \\
\hline DWA & Du & $5 / 5$ & 167.5 & 1.5 & 5.4 & 198 \\
DWB & Du & $4 / 5$ & 164.0 & -2.5 & 13.4 & 47 \\
DMA & Dm & $5 / 5$ & 180.6 & 4.3 & 11.4 & 46 \\
DPA* & Dm & $6 / 6$ & 161.2 & -1.9 & 7.4 & 82 \\
NYD 1 & Du & $5 / 5$ & 172.3 & 5.1 & 16.8 & 22 \\
NYD 2 & Du & $5 / 5$ & 179.3 & 3.7 & 15.1 & 26 \\
NYD 3 & Du & $4 / 5$ & 173.6 & 5.1 & 15.7 & 35 \\
NYD 4 & Du & $5 / 5$ & 174.7 & -2.4 & 13.9 & 31 \\
NYD 5 & Du & $4 / 5$ & 177.2 & -1.4 & 22.3 & 18 \\
All samples & & $43 / 46$ & 172.0 & 1.2 & 3.8 & 33 \\
All sites & & $9 / 9$ & 172.3 & 1.0 & 4.7 & 116 \\
\hline
\end{tabular}

Sites collected from Upper Devonian (Du) and Middle Devonian (Dm) formations (see Table Al). $R s$ is the ratio of samples or sites used in calculating mean direction to the number of samples or sites collected (rejected samples were thermally unstable); $\alpha_{95}$ is the radius (in degrees) of the circle of $95 \%$ confidence about the mean direction $[R$. A. Fisher, 1953]; $k$ is the best estimate of Fisher's precision parameter; the polar errors ( $d p$ and $d m$ ) are the semiaxes of the oval of $95 \%$ confidence about the pole, $d p$ being along the paleomeridian direction and $d m$ perpendicular to it. The mean pole position from nine site poles in $46.8^{\circ} \mathrm{N}, 116.6^{\circ} \mathrm{E}, A_{05}=4.4^{\circ}$, and $K=136$. The mean pole position from the mean direction of nine sites is $46.8^{\circ} \mathrm{N}, 116.7^{\circ} \mathrm{E}, d p=2.4^{\circ}$, and $d m=4.7^{\circ}$.

${ }^{*}$ One sample from this site gave a direction (inclination, $-6.5^{\circ}$; declination, $338.0^{\circ}$ ) antiparallel to all other samples; this direction was inverted to calculate the site mean.

\section{Comparison With Other Data}

Table 2 contains a summary of reported Devonian and Early Carboniferous (Mississippian) paleomagnetic pole positions for North America; included also are the mean Late Carboniferous (Pennsylvanian), Early Permian, and Late Permian pole positions calculated by Van der Voo and French [1974] from what they considered the best available data. These poles are plotted in Figure 9. Older results from the Middle Devonian Onondaga limestone [Graham. 1954] and the Barnett Formation of Mississippian age [Howell and Martinez, 1957] (not listed in Table 2) were based on undemagnetized NRM, which is apt to be contaminated by secondary magnetization, and therefore are not considered further here.

Comparison of the Catskill pole with the other middle to late Paleozoic paleomagnetic poles from North America shows (1) that it is near the Permian pole position and (2) that it agrees well with certain Devonian poles but disagrees by about $15^{\circ}$ with others. Because of the few experimentally reliable Devonian poles available it is possible to average all the Devonian poles to obtain a better estimate of the paleo-

TABLE 2. Middle to Late Paleozoic Paleomagnetic Poles for North America

\begin{tabular}{|c|c|c|c|c|c|}
\hline Identification & Rock Unit & Location & Age & Pole Position & Reference \\
\hline $\begin{array}{l}\text { D1 } \\
\text { D2 } \\
\text { D3 } \\
\text { D4 } \\
\text { D5 } \\
\text { D6 } \\
\text { D7 }\end{array}$ & $\begin{array}{l}\text { Clam Bank Group } \\
\text { Perry Formation volcanics } \\
\text { Perry Formation red beds } \\
\text { Perry Formation volcanics } \\
\text { Perry Formation red beds } \\
\text { low-grade metavolcanics } \\
\text { Columbus limestone (reversed } \\
\text { directions) }\end{array}$ & $\begin{array}{l}\text { Newfoundland } \\
\text { New Brunswick } \\
\text { New Brunswick } \\
\text { Maine } \\
\text { New Brunswick } \\
\text { Massachusetts } \\
\text { Ohio }\end{array}$ & $\begin{array}{l}\text { Dl } \\
\text { Du } \\
\text { Du } \\
\text { Du } \\
\text { Du } \\
\text { D } \\
\text { Dl }\end{array}$ & $\begin{array}{l}28^{\circ} \mathrm{N}, 146^{\circ} \mathrm{E} \\
26^{\circ} \mathrm{N}, 109^{\circ} \mathrm{E} \\
35^{\circ} \mathrm{N}, 121^{\circ} \mathrm{E} \\
24^{\circ} \mathrm{N}, 128^{\circ} \mathrm{E} \\
32^{\circ} \mathrm{N}, 118^{\circ} \mathrm{E} \\
26^{\circ} \mathrm{N}, 122^{\circ} \mathrm{E} \\
45^{\circ} \mathrm{N}, 120^{\circ} \mathrm{E}\end{array}$ & $\begin{array}{l}\text { Black [1964] } \\
\text { Black [1964] } \\
\text { Black [1964] } \\
\text { Phillips and Heroy. [1966] } \\
\text { Robertson et al. [1968] } \\
\text { Brecher et al. [1974] } \\
\text { Martin [1975] }\end{array}$ \\
\hline $\begin{array}{l}\text { D8 } \\
\text { D9 } \\
\mathrm{Cl} 1 \\
\mathrm{Cl} 2 \\
\mathrm{Cl} 3 \\
\mathrm{Cl} 4 \\
\mathrm{Cl} 5 \\
\mathrm{Cu} 1\end{array}$ & $\begin{array}{l}\text { Delaware limestone } \\
\text { Catskill red beds } \\
\text { Codroy Group } \\
\text { Maringoin Formation } \\
\text { pre-Pictou sandstone } \\
\text { Hopewell Group } \\
\text { Mauch Chunk Formation } \\
\text { Maroon Formation }\end{array}$ & $\begin{array}{l}\text { Ohio } \\
\text { New York } \\
\text { Newfoundland } \\
\text { New Brunswick } \\
\text { New Brunswick } \\
\text { New Brunswick } \\
\text { Pennsylvania } \\
\text { Colorado }\end{array}$ & $\begin{array}{l}\mathrm{Dm} \\
\mathrm{Dm}-\mathrm{Du} \\
\mathrm{Cl} \\
\mathrm{Cl}(\mathrm{u}) \\
\mathrm{Cl}(\mathrm{u})-\mathrm{Cu}(1) \\
\mathrm{Cl}(\mathrm{u})-\mathrm{Cu}(\mathrm{l}) \\
\mathrm{Cl}(\mathrm{u}) \\
\mathrm{Cu}\end{array}$ & $\begin{array}{l}48^{\circ} \mathrm{N}, 118^{\circ} \mathrm{E} \\
47^{\circ} \mathrm{N}, 117^{\circ} \mathrm{E} \\
30^{\circ} \mathrm{N}, 127^{\circ} \mathrm{E} \\
34^{\circ} \mathrm{N}, 117^{\circ} \mathrm{E} \\
24^{\circ} \mathrm{N}, 133^{\circ} \mathrm{E} \\
34^{\circ} \mathrm{N}, 118^{\circ} \mathrm{E} \\
43^{\circ} \mathrm{N}, 127^{\circ} \mathrm{E} \\
41^{\circ} \mathrm{N}, 133^{\circ} \mathrm{E}\end{array}$ & 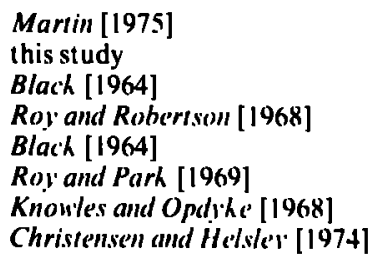 \\
\hline Identification & Geologic Series & \multicolumn{2}{|c|}{ Number of Poles in Mean } & Pole Position & Reference \\
\hline $\begin{array}{l}\text { CU } \\
\text { PL } \\
\text { PU }\end{array}$ & $\begin{array}{l}\text { Upper Carboniferous } \\
\text { Lower Permian } \\
\text { Upper Permian }\end{array}$ & \multicolumn{2}{|c|}{$\begin{array}{l}8 \\
5 \\
4\end{array}$} & $\begin{array}{l}40^{\circ} \mathrm{N}, 130^{\circ} \mathrm{E} \\
43^{\circ} \mathrm{N}, 125^{\circ} \mathrm{E} \\
49^{\circ} \mathrm{N}, 113^{\circ} \mathrm{E}\end{array}$ & $\begin{array}{l}\text { Van der Voo and Fremsh }[1974] \\
\text { Van der Voo and French }[1974] \\
\text { Van der Voo and French }[1974]\end{array}$ \\
\hline
\end{tabular}

$\mathrm{D}$ is Devonian; $\mathrm{Cl}$ and $\mathrm{Cu}$ are Lower and Upper Carboniferous, respectively. Lower, middle, and upper divisions are indicaled by I, m. and u, respectively. 


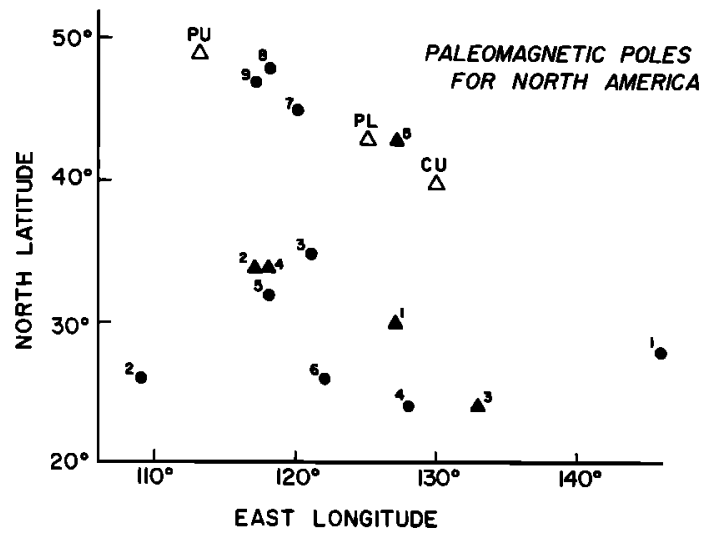

Fig. 9. Plot of middle to late Paleozoic pole positions from North America. The solid circles represent Devonian, and the adjacent numbers refer to the poles with a D prefix in Table 2. The solid triangles represent Lower Carboniferous, and the adjacent numbers refer to poles with a $\mathrm{Cl}$ prefix in Table 2 . The locations of sampling localities for these poles are shown in Figure 10. The open triangles represent mean Upper Carboniferous (CU) and Lower (PL) and Upper (PU) Permian pole positions for North America listed in Table 2 from Van der Voo and French [1974].

magnetic field relative to North America for this time. For validity this would need to assume that the large scatter in the pole positions reflects random errors, such as unaveraged secular variation, for which there is little justification. Alterna- tively, those Devonian results which give poles near the Permian position could be considered to reflect a late Paleozoic remagnetization [e.g., Creer, 1970] and should not be included. It is difficult to envisage, however, the mechanism by which such different types of rocks (gray-colored limestones (D7 and D8) and the red beds from the Catskills) situated some $1000 \mathrm{~km}$ apart in different geological settings should both have become remagnetized in the Permian. In addition, the lack of experimental evidence pointing to later remagnetization of these rocks suggests that some other reason should be sought for the apparent discordance in the North American Devonian paleomagnetic data.

We note that there appears to be a geographic distinction between the two sets of Devonian data. That is, the Devonian results which give poles at lower latitudes were obtained from localities from the coastal Maritime provinces of Canada and from eastern New England (poles D1, D2, D3, D4, D5, and D6 (Table 2)), whereas those which give an apparent position near the Permian pole are from farther west, from within the continental interior (poles D7, D8, and D9 (Figure 10)). A similar grouping and similar directions seem to occur for Early Carboniferous (Mississippian) paleomagnetic data: the available poles $(\mathrm{Cl} 1, \mathrm{Cl} 2, \mathrm{Cl} 3$, and $\mathrm{Cl} 4$ (Table 2)) from the Canadian Maritimes group near to the Devonian poles from the same areas, but the pole from the Mauch Chunk Formation of Pennsylvania, on the west side of the Appalachians $(\mathrm{Cl}$ 5), plots again at higher latitude, near the Permian pole posi-

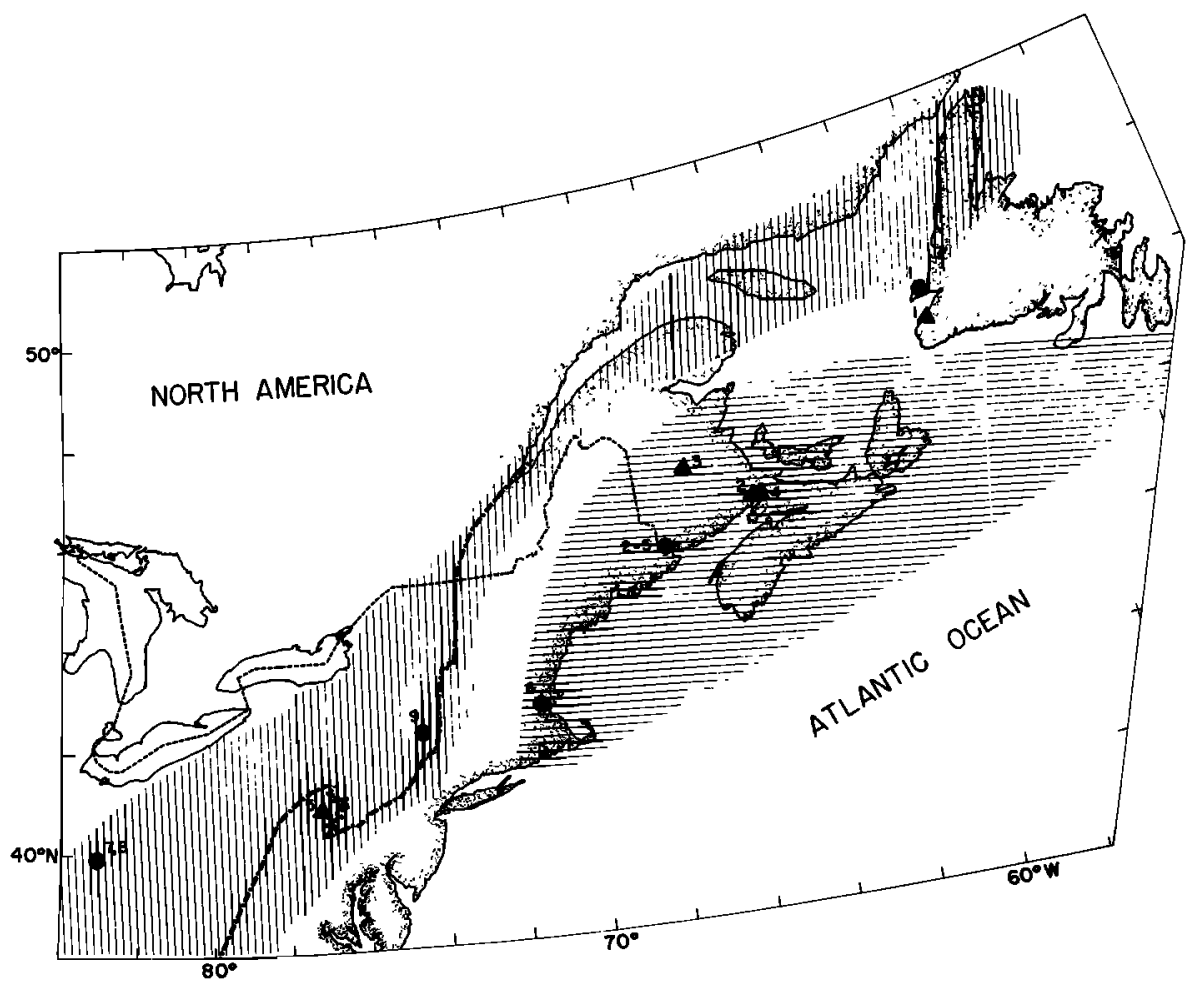

Fig. 10. Geographic locations of Devonian and Lower Carboniferous paleomagnetic sampling localities in North America. The solid circles represent Devonian, and the adjacent numbers refer to poles with a $D$ prefix in Table 2. The solid triangles represent Lower Carboniferous, and the adjacent numbers refer to poles with a $\mathrm{Cl}$ prefix in Tible 2. The corresponding pole positions are plotted in Figure 9. Horizontal hatching and vertical hatching are schemitic representiltions of Old World and Appalachian brachiopod provinces, respectively, for the Early Devonian [from J. G. Johnson and A. J. Boucot, 1973]. The dot-dashed line is the approximate position of the Appalachian structural front. The dashed line is the political boundary between Canada and the United States. 


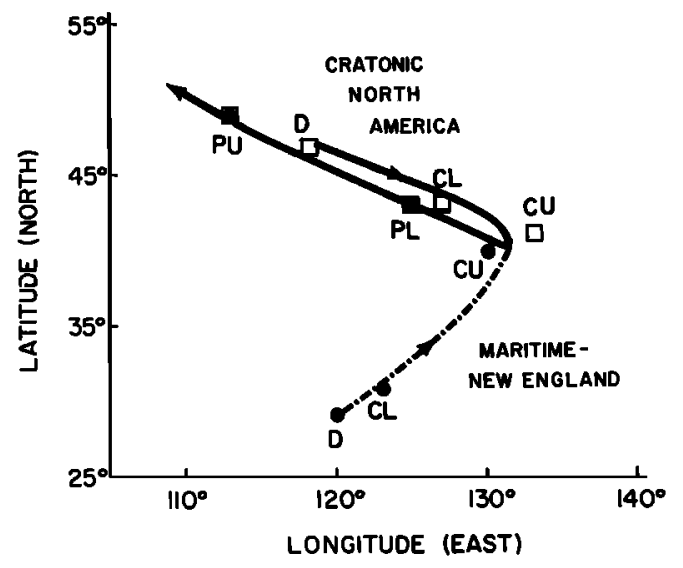

Fig. 11. Preferred apparent polar wander paths for cratonic North America (solid curve) and for the Canadian Maritime-coastal New England region (dot-dashed curve) in the middle to late Paleozoic, showing convergence to a common path in the Late Carboniferous. Data from Table 2 were used to obtain the mean paleomagnetic pole positions for cratonic North America (squares: Devonian (D), poles D7-D9, latitude $=46.6^{\circ} \mathrm{N}$, longitude $=118.3^{\circ} \mathrm{E}$, and $A_{0 s}=2.8$; Lower Carboniferous (CL), pole $\mathrm{Cl} \mathrm{5;}$ Upper Carboniferous (CU), pole $\mathrm{Cu} 1$; Lower Permian (PL); and Upper Permian (PU) [Van der Voo and French, 1974]) and for the Maritime-New England region (solid circles: Devonian (D), poles D2-D6, latitude $=28.7^{\circ} \mathrm{N}$, longitude $=$ $119.6^{\circ} \mathrm{E}$, and $\left.A_{\mathrm{gg}}=7.3^{\circ}\right)$; Lower Carboniferous ( $\mathrm{CL}$ ), poles $\mathrm{Cl} 2-\mathrm{Cl} 4$, latitude $=30.8^{\circ} \mathrm{N}$, longitude $=122.9^{\circ} \mathrm{E}$, and $A_{25}=14.8^{\circ} ;$ and Upper Carboniferous (CU) [Van der Voo and French, 1974]). Poles from Newfoundland ( $\mathrm{Dl}$ and $\mathrm{Cl} 1$ in Table 2) were not used in calculating mean pole positions because of possible additional tectonic complexity.

tion for North America (Figure 10). We therefore consider on the basis of these consistent relationships that the coastal Canadian Maritime and New England region did not share a common polar wander path with cratonic North America for at least part of the Devonian and Carboniferous periods. Our interpretation of the middle to late Paleozoic paleomagnetic data for cratonic North America and for the coastal New England-Maritime region is shown in Figure 11. Paleomagnetic data (poles D1 and $\mathrm{Cl} 1$ ) from Newfoundland are not considered in this analysis because of possible additional tectonic complication [Black, 1964: Robertson et al., 1968; Deutsch and Rao, 1977].

This interpretation of the data places the Devonian paleomagnetic pole near the Permian position with respect to cratonic North America but at lower latitudes with respect to the Maritime-New England region. Between the Early and Late Carboniferous, there was an apparent polar shift of about $13^{\circ}$ for the coastal Maritime-New England region; this shift has been noted previously by Roy and Robertson [1968] and others. However, the pattern of apparent polar wander over this same time interval for cratonic North America, and hence the times at which the two areas began to share a common polar path, is not clear. This is largely because the best estimate of the North American Late Carboniferous paleomagnetic pole as calculated by Van der Voo and French [1974] is based on data obtained only from the Maritime-New England region and because there are few reliable Carboniferous paleomagnetic data that can be considered to be representative of cratonic North America. These few data, i.e., the Lower Carboniferous Mauch Chunk pole (Cl 5 (Table 2)) and a preliminary paleo- magnetic pole ( $\mathrm{Cu} 1$ (Table 2)) reported for the Upper Carboniferous part of the Maroon Formation of Colorado [Christensen and Helsely, 1974], suggest to us an apparent polar shift for cratonic North America during the Carboniferous to near the Upper Carboniferous pole position for the Maritime-New England region (Figure 11). The apparent polar wander path for cratonic North America thus appears to make a tight loop or hairpin in the late Paleozoic with the Maritime-New England path joining it at the switch in direction in the Late Carboniferous. Clearly, though, additional paleomagnetic data are required to define the Carboniferous segment of the apparent polar wander path for cratonic North America.

\section{Discussion}

Assuming a geocentric axial dipole field, dissimilar apparent polar wander path segments obtained from different regions within a continent imply that these regions were once separate and moved in relation to each other. There may be other reasons for discordant paleomagnetic poles, such as local tectonic rotations, but when such discordances occur consistently on a regional scale, they strongly suggest that continental drift is responsible. Therefore the time at which the apparent polar wander paths converge and give a common path indicates joining of the once separate regions to form a single landmass.

Wilson [1966] has suggested on geologic grounds that a proto-Atlantic Ocean existed in approximately the same location as the present North Atlantic during the early Paleozoic which then closed by stages during the middle and late Paleozoic, bringing together the surrounding continents. Subsequently, the supercontinent thus formed again broke apart and the present Atlantic Ocean began to form sometime in the Mesozoic. However, he suggests that the reopening did not follow exactly the line of suture formed by the closing of the proto-Atlantic with the result that some coastal regions have been transposed. This history was proposed largely to account for the present geographic distribution of early Paleozoic faunal realms in the North Atlantic. However, it is noteworthy that the present geographic distribution of Devonian brachiopod provinces in the Atlantic-bordering continents [J. G. John-

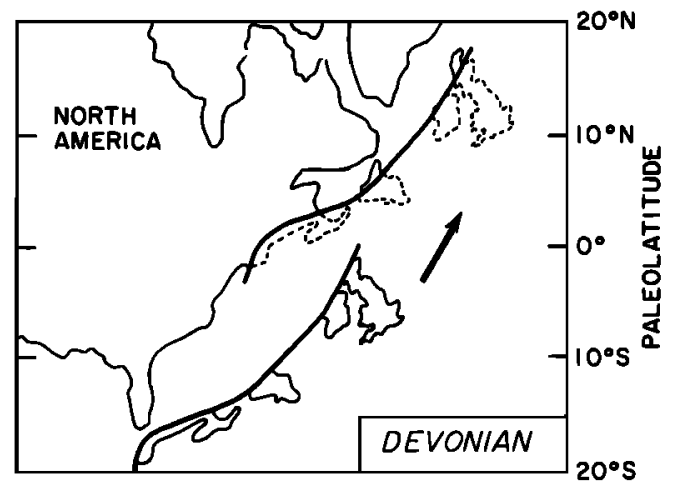

Fig. 12. Paleogeographic sketch of North America in the Devonian showing the position of the New England-Maritime region, along with parts of the British Isles, with respect to the North American craton. The paleolatitude framework is based on the mean Devonian pole position for each area as shown in Figure 11. The arrow shows the inferred sense of motion during the Carboniferous which brought the Maritime-New England-British Isles area to the position shown by the dashed outline (see text). 
son and $A . J$. Boucot, 1973] apparently can also be accounted for by the Wilson cycle of opening and closing of oceans. McKerrow and Ziegler [1972] pursued Wilson's idea further and applied the concepts of plate tectonics in interpreting certain orogenic zones as sutures where continental collisions closed previously existing oceans. In particular, they considered the Acadian orogeny in the Middle Devonian to be due to the collision of part of the Baltic Shield (eastern Newfoundland to Massachusetts) with the Canadian Shield, closing the proto-Atlantic.

Our interpretation of middle to late Paleozoic paleomagnetic data from North America provides support for the idea that the coastal Maritime-New England region was separate from cratonic North America sometime during the Paleozoic. However, this interpretation is in apparent disagreement with the timing proposed by McKerrow and Ziegler [1972] for their unification: the paleomagnetic evidence suggests relative motion between these blocks until about the Late Carboniferous (Figure 11), whereas McKerrow and Ziegler's tectonic analysis implies suturing in the Devonian. In support of their view they cite evidence from freshwater fish faunas which suggests that there was a land connection between the Canadian and Baltic shields starting in the Middle Devonian. Moreover, we are not aware of any geologic evidence in support of the existence of any substantial ocean in New England or the Canadian Maritimes that closed in the late Paleozoic. On the other hand the presence of an extensive system of northeast-southwest trending faults in this region, believed to be mostly strike slip and active primarily in the Carboniferous [ $W e b b, 1969]$, points to a means of reconciling the apparent conflict between the paleomagnetic and tectonic estimates of the suture age. We suggest that the relative motion between the Maritime-New England region and cratonic North America was largely along these shear zones during the Carboniferous, perhaps in response to the approach of Africa and its subsequent collision with North America to form the Appalachians to the south. Unlike the main collision apparently responsible for the Devonian Acadian orogeny in the Maritimes and New England, which produced regional folding and metamorphism, the subsequent shearing in the Carboniferous generally caused fault-bounded basins filled with primarily restricted marine and terrestrial sediment, which have been locally (e.g., Narragansett Basin) metamorphosed [Kay and Colbert, 1965]. We estimate the cumulative left lateral relative movement in the Carboniferous to be of the order of $1500 \mathrm{~km}$ (the equivalent of $15^{\circ}$ of latitude), which brought the Maritime-New England region from southern hemisphere paleolatitudes northward to the equatorial regions then occupied by the now contiguous part of cratonic North America (Figure 12).

Morris [1976] recently compared paleomagnetic pole positions from North America and western Europe (particularly England), representing the time interval from the late Precambrian to the Devonian. His interpretation of the paleomagnetic data indicated that the southern part of England occupied a more southerly position with respect to North America in the lower Paleozoic and subsequently moved northward during the Devonian. By the end of the Devonian, England and North America were together as part of Euramerica in a configuration similar to the morphological fit of continents described by Bullard et al. [1965], a conclusion reached previously by Roy [1972] in his analysis of Late Devonian to early Mezozoic paleomagnetic data from eastern North America and western Europe.

In Morris's analysis the paleomagnetic pole positions that were considered to be representative of North America for the Late Devonian, and which in fact constrained the inferred timing of relative motion with respect to England, were obtained from the Canadian Maritimes and northern New England (i.e., the Perry Formation); North American paleomagnetic data for earlier geologic periods came from outside this region. In addition to using this same set of Late Devonian paleomagnetic pole positions, Roy [1972] considered Carboniferous paleomagnetic data which also were entirely derived from studies of rocks from the Canadian Maritimes as being representative of North America. However, we believe that the paleomagnetic and geologic evidence is consistent with the idea that the Canadian Maritime-coastal New England region was not firmly attached to North America until the Late Carboniferous. We would therefore interpret the apparent close agreement between paleomagnetic poles from Britain and the Canadian Maritimes for the Late Devonian and the Lower Carboniferous demonstrated by Morris [1.976] and Roy [1972] as evidence that these regions were possibly attached yet distinct from cratonic North America. This would imply that England shared the same translation relative to cratonic North America with the coastal New England-Maritime region during the Carboniferous, as sketched in Figure 12. The apparent discordance of Silurian-Lower Devonian paleomagnetic poles between Britain and the Baltic area [Briden et al., 1973] suggests that the Baltic-Russian area need not have a similar history of motion with respect to North America as is suggested for Britain.

TABLE A1. Location of Sampling Sites

\begin{tabular}{|c|c|c|c|c|c|}
\hline Site & Formation & Age & Latitude, ${ }^{\circ} \mathbf{N}$ & Longitude, ${ }^{\circ} \mathbf{W}$ & Description \\
\hline $\begin{array}{l}\text { DPA } \\
\text { DMA } \\
\text { DWA }\end{array}$ & $\begin{array}{l}\text { Plattekill } \\
\text { Manorkill } \\
\text { Walton }\end{array}$ & $\begin{array}{l}\mathrm{Dm} \\
\mathrm{Dm} \\
\mathrm{Du}\end{array}$ & $\begin{array}{l}42.11 \\
42.38 \\
42.07\end{array}$ & $\begin{array}{l}74.05 \\
74.40 \\
75.32\end{array}$ & $\begin{array}{l}\text { West Saugerties, stream bed at bridge } \\
\text { stream bed, } 1.5 \mathrm{mi}(2.4 \mathrm{~km}) \text { west of Conesville } \\
\text { drainage ditch along route } 97,1 \mathrm{mi}(1.6 \mathrm{~km}) \text { south of Can- } \\
\text { nonsville Reservoir }\end{array}$ \\
\hline $\begin{array}{l}\text { DWB } \\
\text { NYD } 1\end{array}$ & $\begin{array}{l}\text { Walton } \\
\text { Walton }\end{array}$ & $\begin{array}{l}\text { Du } \\
\text { Du }\end{array}$ & $\begin{array}{l}42.03 \\
41.6\end{array}$ & $\begin{array}{l}75.07 \\
74.65\end{array}$ & $\begin{array}{l}\text { outcrop along route } 30,4.7 \mathrm{mi}(7.5 \mathrm{~km}) \text { north of Harvard } \\
\text { outcrop along route } 17,0.5 \mathrm{mi}(0.8 \mathrm{~km}) \text { north of exit } 104 \\
\text { (Whitelake) }\end{array}$ \\
\hline NYD 2 & Walton & Du & 41.82 & 74.67 & $\begin{array}{l}\text { outcrop along route } 44,5.5 \mathrm{mi}(8.8 \mathrm{~km}) \text { north of Liberty, } \\
\text { near Bradley }\end{array}$ \\
\hline $\begin{array}{l}\text { NYD } 3 \\
\text { NYD } 4 \\
\text { NYD } 5\end{array}$ & $\begin{array}{l}\text { Walton } \\
\text { Walton } \\
\text { Walton }\end{array}$ & $\begin{array}{l}\mathrm{Du} \\
\mathrm{Du} \\
\mathrm{Du}\end{array}$ & $\begin{array}{l}41.86 \\
41.84 \\
41.77\end{array}$ & $\begin{array}{l}75.78 \\
74.75 \\
74.74\end{array}$ & $\begin{array}{l}\text { outcrop along route } 17,0.5 \mathrm{mi}(0.8 \mathrm{~km}) \text { west of Parksville } \\
\text { outcrop along route } 17,1 \mathrm{mi}(1.6 \mathrm{~km}) \text { east of Parksville } \\
\text { outcrop along route } 17 \text {, at exit } 101 \text { (Ferndale) }\end{array}$ \\
\hline
\end{tabular}

Dm is Middle Devonian, and Du is Upper Devonian. 
Acknowledgments. We thank R. A. Schweickert and T. Engelder for critically reading the manuscript and offering helpful comments. The reviewers also provided useful criticism. The field assistance of C. A. Kent in collecting many of the samples is appreciated. This work was supported by the National Science Foundation, grant EAR 7518955. Lamont-Doherty Geological Observatory contribution number 2710

\section{REFERENCES}

Black, R. F., Paleomagnetic support of the theory of rotation of western part of the island of Newfoundland, Nature, 202, 945-948, 1964.

Brecher, A., J. Nabelek, L. D. Schutts, and P. M. Hurley, Resetting of paleomagnetic remanence in low-grade metavolcanics (abstract), Eos Trans. $A G U, 55,234,1974$.

Briden, J. C., W. A. Morris, and J. D. A. Piper, Paleomagnetic studies British Caledonides, VI, Regional and global implications, Geophys. J. Roy. Astron. Soc., 34, 107-134, 1973.

Bullard, E. C., J. E. Everett, and A. G. Smith, A symposium on continental drift, IV, The fit of the continents around the Atlantic, Phil. Trans. Roy. Soc. London, Ser. A, 258, 41-51, 1965.

Christensen, E. D., and C. E. Helsley, Paleomagnetic results from the late Paleozoic Maroon Formation (abstract), Eos Trans. $A G U, 55$. 225,1974

Creer, K. M., A review of paleomagnetism, Earth Sci. Rev., 6, 369-466, 1970.

Deutsch, E. R., and K. V. Rao, New paleomagnetic evidence fails to support rotation of western Newfoundland, Nature, 266, 314-318, 1977.

Dunlop, D. J., Magnetic mineralogy of unheated and heated red sediments by coercivity spectrum analysis, Geophys. J. Roy. Astron. Soc., 27, 37-55, 1972.

Fisher, D. W., Y. W. Isachsen, and L. V. Rickard (Eds.), Geologic map of New York, N. Y. State Mus. Sci. Serv., Albany, N. Y., 1970.

Fisher, R. A., Dispersion on a sphere, Proc. Roy. Soc. London, Ser. A, 217, 295-305, 1953.

Fletcher, F. W., Middle and Upper Devonian clastics of the Catskill front, New York, in Field Guide Book, edited by R. H. Waines, pp. Cl-28, New York State Geological Association, Albany, N. Y., 1967.

Graham, J. W., The stability and significance of magnetism in sedimentary rocks, J. Geophys. Res., 54, 131-167, 1949.

Graham, J. W. Rock magnetism and the earth's magnetic field in Paleozoic time, J. Geophys. Res., 59, 215-222, 1954.

Howell, L. G., and J. D. Martinez, Polar movement as indicated by rock magnetism, Geophysics, 22, 384-397, 1957.

Irving, E., and N. D. Opdyke, The paleomagnetism of the Bloomsburg red beds and its possible application to the tectonic history of the Appalachians, Geophys. J. Roy. Astron. Soc., 9. 153-166, 1965.

Johnson, H. P., H. Kinoshita, and R. T. Merrill, Spinel formation by heating haematite in air and water vapour, Nature London Phys. Sci. 239(96), 151-152, 1972.

Johnson, J. G., and A. J. Boucot, Devonian brachiopods, in Atlas of Paleobiogeography, edited by A. Hallam, pp. 89-96, Elsevier, New York, 1973

Kay, M., and E. H. Colbert, Stratigraphy and Life History, 736 pp., John Wiley, New York, 1965.

Knowles, R. R., and N. D. Opdyke, Paleomagnetic results from the Mauch Chunk Formation: A test of the origin of curvature in the folded Appalachians of Pennsylvania, J. Geophys. Res., 73, 65156526, 1968.

Martin, D. L., A paleomagnetic polarity transition in the Devonian Columbus limestone of Ohio: A possible stratigraphic tool, Tectonophysics, 28, 125-134, 1975.

McKerrow, W. S., and A. M. Ziegler, Paleozoic oceans, Nature London Phys. Sci. 240, 92-94, 1972.

Molyneux, L., Complete results magnetometer for measuring the remanent magnetism of rock and mud samples (abstract) Eos Trans. AGU, 53, 357, 1972.

Morris, W. A., Transcurrent motion determined paleomagnetically in the northern Appalachians and Caledonides and the Acadian orogeny, Can. J. Earth Sci., 13, 1236-1243, 1976.

Phillips, J. D., and P. B. Heroy, Paleomagnetic results from the Devonian Perry lavas near Eastport, Maine (abstract), Eos Trans. $A G U, 47,80,1966$.

Robertson, W. A., J. L. Roy, and J. K. Park, Magnetization of the Perry Formation of New Brunswick and the rotation of Newfoundland, Can. J. Earth Sci., 5, 1175-1181, 1968.

Roy, J. L., A pattern of rupture of the eastern North AmericanWestern European paleoblock, Earth Planet. Sci. Lett., 14, 103-114, 1972.

Roy, J. L., and J. K. Park, Paleomagnetism of the Hopewell Group, New Brunswick, J. Geophys. Res., 74, 594-604, 1969.

Roy, J. L., and W. A. Robertson, Evidence for diagenetic remanent magnetization in the Maringouin Formation, Can. J. Earth Sci., 5 , 275-285, 1968.

Van der Voo, R., and R. B. French, Apparent polar wandering for the Atlantic-bordering continents: Late Carboniferous to Eocene, Earth Sci. Rev., 10, 99-119, 1974.

Webb, G. W. Paleozoic wrench faults in Canadian Appalachians, in North Atlantic-Geology and Continental Drift, mem. 12, edited by M. Kay, pp. 754-788, American Association of Petroleum Geologists, Tulsa, Okla., 1969.

Wilson, J. T., Did the Atlantic close and then re-open?, Nature, 211 676-681, 1966.

Zijderveld, J. D. A., AC demagnetization of rocks: Analysis of results, in Methods in Paleomagnetism, edited by D. W. Collinson, K. M. Creer, and S. K. Runcorn, pp. 254-286, Elsevier, New York, 1967.

(Received November 28, 1977; revised June 6, 1978; accepted June 6, 1978.) 